\title{
15 Studies of Poems
}

Several poets have died by suicide, and so it of interest to explore whether changes occurred in their poems as they day of their death grew closer.

\subsection{Sara Teasdale ${ }^{47}$}

Sara Teasdale (August 8, 1884 - January 29, 1933) was an American poet from Missouri. After her father died in 1914, Sara married a local businessman, but the marriage was one of convenience. Sara was frigid and used mild illnesses as an excuse to get away from him. Sara divorced him in 1929. From that time on, she lived alone in a hotel, with only visits from a close friend to cheer her up. She became depressed and worried about her health and her finances. She killed herself in her bathtub with an overdose of sedatives.

Drake (1979) noted that four major women poets of the $19^{\text {th }}$ Century (Emily Bronte, Christina Rossetti, Emily Dickinson and Elizabeth Barrett Browning until she was forty) were all recluses like Sara. All four belonged to very close family units which fulfilled their desires for affection and intellectual stimulation. Sara ventured out more than some of her predecessors but continually retreated into seclusion because of her "illnesses," becoming almost a total recluse by the end of her life.

The Victorian era encouraged women in the creative arts but undermined their self-confidence. They were allowed to dabble, but they were not supposed to achieve. When they did write poetry, they wrote mostly about love and the desire to submit to the ideal lover. However, it was not always easy to find this in their own lives. They often ended up renouncing love for men and substituting an attraction to death. They frequently had mysterious physical weaknesses and chronic ill health, a neurotic way of resolving the conflict between their personal desires and the conventions imposed upon them by the society.

The present analysis examined the poems of Sara Teasdale (Teasdale, 1938) for changes in their content from her first collection (in 1907) to her final (and $7^{\text {th }}$ ) collection (in 1933). Each of the 317 poems was labeled by the year of the collection that they appeared in (from 1907 to 1933). There were 25 significant correlations out of 74 examined, significantly more than would be expected by chance (see Table 15-1). The two most interesting trends were: (1) a decrease in positive emotions and feelings over time, and (2) fewer references to herself and to others. There was no change in the use of words related to death, but there were fewer references to religion and to physical states and functions, the body, sexual activities and sleep. There was a decrease in references to the present and an increase in references to the future.

47 This section was co-authored with Stephanie McSwain. 
Tab. 15.1: Correlations over time for the poems of Sara Teasdale, numbered by the year of the book in which they appeared

\section{Pearson $r$}

\begin{tabular}{|c|c|}
\hline Word count & $-0.15^{\star *}$ \\
\hline Words per sentence & $0.15^{\star \star}$ \\
\hline Unique words & $0.19^{\star \star}$ \\
\hline Words long than 6 letters & $0.13^{*}$ \\
\hline Pronouns & $-0.15^{\star \star}$ \\
\hline First person singular & $-0.16 * \star$ \\
\hline Total first person & $-0.15^{\star \star}$ \\
\hline Total third person & $-0.13^{\star}$ \\
\hline Negations & $0.14^{\star}$ \\
\hline Affect & $-0.15^{\star *}$ \\
\hline Positive emotions & $-0.13^{*}$ \\
\hline Positive feelings & $-0.18 * \star$ \\
\hline Social processes & $-0.12^{\star}$ \\
\hline Time & $0.13^{*}$ \\
\hline Present tense verbs & $-0.12^{\star}$ \\
\hline Future tense verbs & $0.16^{\star \star}$ \\
\hline Space & $0.17^{\star \star}$ \\
\hline Up & $0.20^{\star \star}$ \\
\hline Motion & $0.14^{*}$ \\
\hline Occupation & $0.11^{\star}$ \\
\hline Religion & $-0.16 * \star$ \\
\hline Physical states & $-0.34^{\star \star}$ \\
\hline Body & $-0.26^{\star \star}$ \\
\hline Sexual & $-0.23^{\star \star}$ \\
\hline Sleep & $-0.14^{\star}$ \\
\hline Prepositions & $0.10 \#$ \\
\hline Senses & $-0.09 \#$ \\
\hline Other references to people & $-0.10 \#$ \\
\hline Metaphysical issues & $-0.11 \#$ \\
\hline
\end{tabular}

* two-tailed $p<.05, * \star$ two-tailed $p<.01, \#$ trend (two-tailed $p<0.10$ )

Some of these trends have psychodynamic significance. For example, there was a decline in positive emotions and feelings in the later poems, in contrast to the 
increase in positive emotions in Katie's diary (Chapter 3), and the poems also became more impersonal, with fewer references to herself and to others.

Poems are crafted to a much great extent than diary entries and letters, and so much of the "personal" content may be eliminated or changed in line with the structure of the poem. It is to be expected, therefore, that poems will be less influenced by the state of mind of the poet than would be diaries and letters.

\subsection{Sylvia Plath ${ }^{48}$}

Sylvia Plath (October 27, 1932 - February 11, 1963) was an American poet who died at the age of thirty in 1963 in England by putting her head in the gas oven. At the time of her death, her husband, the British poet Ted Hughes, had left Sylvia for another woman, leaving Sylvia with two small children and living in an apartment in London. Sylvia probably had a bipolar affective disorder (manic-depressive disorder), and in the final months of her life experienced a creative burst, writing many new poems.

The Collected Poems (Plath, 1981) has the poems organized by the date of writing. The selection of 50 "juvenilia" poems was discarded. The remaining poems start in 1956 and extend through to 1963 . The 224 poems were labeled by the year of writing. Correlations over time were carried out for all 224 poems, for the 69 poems written in the last year of her life and for the 12 poems written in the last month of her life. In addition, the poems written in 1962 were compared by means of t-tests with those written in 1963.

\subsubsection{6-1963}

For all 224 poems written as an adult, there were 29 significant correlations (see Table 15-2). Over this eight year period, positive feelings increased (including optimism) but so did negative emotions. References to herself and to "you" increased. References to the present and future increased, but there no changes in references to the past. References to religion, death and metaphysical issues increased.

\subsubsection{The Last Year}

Fifteen significant correlations were identified for the poems over the last year of her life, more than would be expected by chance (see Table 15-2). The poems got shorter, but with more words per sentence. There were more unique words and fewer question

48 This section was co-authored with Stephanie McSwain. 
marks and words found in dictionaries. Positive emotions increased, but there were fewer words dealing with cognitive mechanisms and insight. There was less focus on the present and more focus on the body and eating. There were no changes in words related to death, religion or metaphysical issues.

Tab. 15.2: The results of the LIWC analysis of Sylvia Path's poems

\begin{tabular}{|c|c|c|c|c|c|}
\hline & \multirow{2}{*}{$\begin{array}{l}\text { By year } \\
n=224\end{array}$} & \multirow{2}{*}{$\begin{array}{l}\text { Over last } \\
\text { year } n=69\end{array}$} & \multirow{2}{*}{$\begin{array}{l}\text { Over last } \\
\text { month } n=12\end{array}$} & \multicolumn{2}{|c|}{1962 versus $1963^{49}$ means } \\
\hline & & & & 1962 & 1963 \\
\hline Word count & $0.15^{\star}$ & $-0.30^{\star}$ & -0.25 & 284.3 & $129.4^{\star}$ \\
\hline Words per sentence & $-0.57^{\star \star}$ & $0.43^{\star \star}$ & -0.18 & 12.2 & $17.0^{\star \star}$ \\
\hline Question marks & $0.36^{\star \star}$ & $-0.30^{\star}$ & 0.02 & 0.94 & $0.42 \#$ \\
\hline Unique words & $-0.53^{\star \star}$ & $0.41^{\star \star}$ & 0.01 & 64.4 & $72.6^{\star \star}$ \\
\hline Words in the dict. & $0.62^{\star \star}$ & $-0.27^{\star}$ & -0.10 & 67.3 & $63.8^{\star}$ \\
\hline Words with $6+$ letters & $-0.29 * \star$ & 0.02 & $-0.56 \#$ & & \\
\hline Pronouns & $0.47^{\star \star}$ & $-0.36^{\star \star}$ & -0.32 & 11.9 & $7.7^{\star \star}$ \\
\hline First person singular & $0.35^{\star \star}$ & -0.11 & -0.47 & & \\
\hline First person plural & -0.09 & $-0.21 \#$ & 0.39 & & \\
\hline Total first person & $0.29^{\star \star}$ & -0.16 & -0.42 & & \\
\hline Total second person & $0.24^{\star \star}$ & -0.16 & -0.17 & 1.9 & $0.7^{\star \star}$ \\
\hline Negations & $0.22^{\star \star}$ & 0.05 & -0.44 & & \\
\hline Assent & 0.01 & 0.01 & - & 0.08 & $0.00 \#$ \\
\hline Articles & $0.43^{\star \star}$ & $0.24 \#$ & 0.18 & & \\
\hline Prepositions & $-0.41^{\star *}$ & $0.30^{\star}$ & 0.27 & 10.3 & $12.7^{\star \star}$ \\
\hline Numbers & 0.08 & $0.23 \#$ & 0.24 & & \\
\hline Affect & $0.13 \#$ & 0.06 & 0.20 & & \\
\hline Positive emotions & 0.05 & $0.24^{\star}$ & 0.04 & & \\
\hline Positive feelings & $0.23^{* \star}$ & -0.01 & -0.21 & & \\
\hline Optimism & $-0.17^{\star *}$ & 0.11 & 0.18 & & \\
\hline Negative emotions & $0.14^{\star}$ & -0.16 & 0.20 & & \\
\hline Anxiety & $0.12 \#$ & -0.08 & 0.49 & & \\
\hline Cognitive processes & 0.06 & $-0.38^{\star \star}$ & -0.20 & & \\
\hline Causation & -0.10 & $-0.23 \#$ & -0.16 & 0.43 & $0.18^{\star}$ \\
\hline Insight & 0.10 & $-0.24^{\star}$ & 0.08 & & \\
\hline Discrepancies & 0.05 & $-0.21 \#$ & -0.23 & & \\
\hline
\end{tabular}

49 Using the t-test for unequal variances. 
Tab. 15.2: The results of the LIWC analysis of Sylvia Path's poems

\begin{tabular}{|c|c|c|c|c|c|}
\hline & \multirow{2}{*}{$\begin{array}{l}\text { By year } \\
n=224\end{array}$} & \multirow{2}{*}{$\begin{array}{l}\text { Over last } \\
\text { year } n=69\end{array}$} & \multirow{2}{*}{$\begin{array}{l}\text { Over last } \\
\text { month } n=12\end{array}$} & \multicolumn{2}{|c|}{1962 versus $1963^{49}$ means } \\
\hline & & & & 1962 & 1963 \\
\hline Inhibition & $-0.14^{\star}$ & -0.18 & -0.34 & & \\
\hline Certainty & 0.06 & $0.24^{*}$ & -0.27 & & \\
\hline Seeing & $-0.12 \#$ & -0.08 & -0.30 & & \\
\hline Social processes & $0.12 \#$ & -0.11 & 0.15 & 7.4 & $4.9^{\star}$ \\
\hline Other refs to people & 0.10 & $-0.21 \#$ & 0.30 & 5.1 & $3.2 \#$ \\
\hline Friends & 0.01 & -0.15 & - & 0.11 & $0.00^{\star \star}$ \\
\hline Humans & 0.08 & $0.20 \#$ & -0.23 & & \\
\hline Past tense verbs & $-0.12 \#$ & -0.16 & -0.12 & & \\
\hline Present tense verbs & $0.57^{\star \star}$ & $-0.47^{\star \star}$ & 0.29 & 9.0 & $6.8^{\star \star}$ \\
\hline Future tense verbs & $0.19^{\star \star}$ & 0.09 & -0.08 & & \\
\hline Up & $-0.12 \#$ & 0.12 & 0.26 & & \\
\hline Exclusive & 0.03 & -0.18 & $-0.66^{\star}$ & & \\
\hline Occupations & $-0.14^{*}$ & 0.05 & 0.26 & & \\
\hline Job & $-0.14^{*}$ & -0.08 & - & 0.13 & $0.00 * \star$ \\
\hline Sports & 0.09 & $0.24^{*}$ & -0.12 & & \\
\hline TV & -0.02 & -0.08 & - & 0.03 & $0.00 *$ \\
\hline Money & $-0.29 \star \star$ & -0.17 & - & 0.13 & $0.00 * \star$ \\
\hline Metaphysical issues & $0.31^{\star \star}$ & 0.08 & -0.15 & & \\
\hline Religion & $0.17^{\star \star}$ & 0.08 & -0.48 & & \\
\hline Death & $0.29^{\star}$ & 0.04 & 0.29 & & \\
\hline Physical states & $0.16^{*}$ & $0.24^{*}$ & -0.14 & & \\
\hline Body & $0.14^{*}$ & $0.22 \#$ & -0.32 & & \\
\hline Sexual & $0.15^{*}$ & 0.06 & -0.28 & & \\
\hline Eating & -0.02 & $0.27^{\star}$ & 0.14 & & \\
\hline Sleep & -0.10 & -0.19 & -0.13 & 0.18 & $0.05 \#$ \\
\hline Grooming & $0.18^{\star \star}$ & 0.03 & 0.31 & & \\
\hline
\end{tabular}

* two-tailed $\mathrm{p}<.05,{ }^{*}$ two-tailed $\mathrm{p}<.01$, \# trend (two-tailed $\mathrm{p}<0.10$ ) 


\subsubsection{The Last Month}

Interestingly, over the last month of her life (see Table 15-2), only one significant trend was found (fewer words of exclusion over time), but one significant correlation in 74 analyses is not a reliable finding.

\subsubsection{Versus 1962}

Fifteen significant differences were found in the poems written in 1963 versus 1962. The poems in the past month of her life were shorter, with more unique words and fewer dictionary words. There were fewer references to "you" and fewer words relevant to causation. Positive and negative emotions did not change. There were fewer references to others and to friends and less emphasis on the present but no changes in words relevant to religion, death or metaphysical issues.

\subsubsection{Discussion}

It has been argued that Plath had a bipolar affective disorder and that she was in a manic phase while writing her final poems. There are many poems from this period, and they are not as well-crafted as her earlier poems. The major trends toward the end of her life were shorter poems, with more unique words and fewer words found in dictionaries. Over the final year, positive emotions became more common, as with Katie's diary (see Chapter 3). There was less emphasis on the present but no changes in words related to death. However, over her life as a poet overall, references to death increased and both positive and negative emotions increased, as did self-references. Unlike the findings in the previous chapter for Sara Teasdale, the changes in Sylvia Plath's poems have more psychodynamic significance, and this is probably a result of Plath's focus on much more personal issues than the poems of Teasdale.

\subsection{Weldon Kees ${ }^{50}$}

Weldon Kees (February 24, 1914 to July 18, 1955) was an American poet who also painted and wrote novels and short stories. On July 19, 1955, his car was found abandoned on the Golden Gate Bridge. There was no suicide note, and no one saw him jump. When friends went to his apartment, his sleeping bag and bank-books were missing. He was presumed to have killed himself.

50 This section was co-authored by Leah Henderson. 
Kees had recently divorced his wife who was an alcoholic and who had psychotic tendencies. In the last few years of his life, Kees showed symptoms of mild mania and abandoned what he was good at (writing poetry) in order to become involved in other projects, few of which came to fruition. In order to keep up with hectic life, he took amphetamines to stay awake and sedatives to go to sleep. In the last few days of his life, he talked about a friend of either jumping off the Golden Gate Bridge or going to Mexico.

Kees wrote three books of poems: The last man in 1943, The fall of the Magician in 1947, and Poems 1947-1954 in 1954. In The collected poems of Weldon Kees (Justice, 2003), there are also 16 poems from the 1940s and 1950s, never collected before, placed in rough chronological order. For the LIWC analysis, each poem in the published books was labeled by the book (1,2 and 3) and all 107 poems were analyzed by the LIWC program and correlated with the book number that the poems were in. Second, the 16 extra poems were numbered by chronological order and their LIWC scores correlated with this number. The results are shown in Table 15-3.

It can be seen that 17 correlations over all 107 of his published poems were statistically significant, but only five over the 16 extra poems. Over the books of his poems, the poems got longer, had more references to himself and fewer to social processes, had fewer references to negative emotions, especially anxiety and to a lesser extent anger, and fewer references to the future. These trends were also apparent to some extent in the 16 extra poems.

It is interesting that in some of the analyses of the present book negative emotions decrease over time and sometimes positive emotions increase over time. We will explore in the final chapter where these trends appeared and whether there is any pattern that can be discerned.

\subsection{Landis Everson ${ }^{51}$}

Landis Everson was born in Colorado in 1926. He finished a Master's degree at Columbia University in 1951, moved to California and wrote poems which were published. He then stopped writing for 43 years, turning to painting for ten years and then remodeling and renovating houses. His next poem, published in 2004, was his first publication since 1962. He published his first book of poems and in 2005 received a prize for the best first book of poems by a poet over 50 . He killed himself with a firearm at the age of 81 on November 17, 2007, after suffering a stroke which left him unable to write.

51 This section was co-authored with Stephanie McSwain. 
Tab. 15.3: Correlations over time for Weldon Kees's poems

\begin{tabular}{|c|c|c|}
\hline & $\begin{array}{l}\text { Correlations by book } \\
(1,2,3) \\
n=107\end{array}$ & $\begin{array}{l}\text { Correlations for the fina } \\
16 \text { poems }(1-16) \\
n=16\end{array}$ \\
\hline Word count & $0.26^{* *}$ & -0.21 \\
\hline Unique words & $-0.20^{\star}$ & -0.08 \\
\hline Words long than 6 letters & $-0.27^{\star \star}$ & $-0.61^{\star}$ \\
\hline First person singular & $0.21^{*}$ & $0.51^{\star}$ \\
\hline Total first person & $0.20^{\star}$ & 0.29 \\
\hline Negation & $-0.25^{\star \star}$ & -0.09 \\
\hline Articles & $0.20^{\star}$ & 0.29 \\
\hline Prepositions & $0.24^{*}$ & $0.52^{\star}$ \\
\hline Affect & 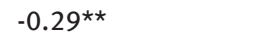 & -0.29 \\
\hline Negative emotions & $-0.25^{\star \star}$ & -0.40 \\
\hline Anxiety & $-0.28^{\star \star}$ & -0.30 \\
\hline Cognitive processes & $-0.21^{\star}$ & $-0.58^{*}$ \\
\hline Senses & $-0.22^{\star}$ & 0.18 \\
\hline Hearing & $-0.20^{\star}$ & 0.17 \\
\hline Social processes & $-0.30^{\star \star}$ & 0.01 \\
\hline Communication & $-0.25^{\star \star}$ & 0.12 \\
\hline Inclusive & $0.29 * *$ & -0.01 \\
\hline Motion & 0.08 & $0.61^{*}$ \\
\hline Words per sentence & $-0.16 \#$ & -0.25 \\
\hline Total third person & $-0.16 \#$ & 0.12 \\
\hline Optimism & -0.10 & $-0.44 \#$ \\
\hline Anger & -0.10 & $-0.44 \#$ \\
\hline Insight & $-0.18 \#$ & -0.37 \\
\hline Tentative & -0.07 & $-0.49 \#$ \\
\hline Seeing & $-0.18 \#$ & 0.14 \\
\hline Other references to people & $-0.19 \#$ & -0.02 \\
\hline Time & $0.18 \#$ & $0.47 \#$ \\
\hline Future & $-0.17 \#$ & -0.41 \\
\hline Music & $-0.17 \#$ & -0.15 \\
\hline Death & $-0.17 \#$ & -0.32 \\
\hline
\end{tabular}


Tab. 15.4: A comparison between the 9 early poems and 66 later poems of Landis Everson (mean scores shown)

\begin{tabular}{lll}
\hline & Early poems & Later poems \\
\hline Negations & 0.82 & $2.07^{\star}$ \\
Anxiety & 0.46 & $0.16^{\star}$ \\
Tentative & 1.02 & $1.70^{\star}$ \\
Past tense verbs & 1.81 & $3.15^{\star \star}$ \\
Inclusive & 7.69 & $5.30^{\star \star}$ \\
Occupations & 0.41 & $1.04^{\star \star}$ \\
School & 0.03 & $0.30^{\star \star}$ \\
Home & 0.10 & $0.32^{\star}$ \\
Word count & 395.11 & $132.32 \#$ \\
Unique words & 64.21 & $70.51 \#$ \\
Humans & 1.06 & $0.29 \#$ \\
Sleep & 0.61 & $0.19 \#$ \\
\hline * two-tailed $\mathrm{p}<.05,{ }^{* \star}$ two-tailed $\mathrm{p}<.01, \#$ trend (two-tailed $\left.\mathrm{p}<0.10\right)$ \\
\hline
\end{tabular}

Everson's poems, therefore, were written in two widely separated eras (Everson, 2006). The 9 early poems are much longer than the later 66 poems, which makes it difficult to compare the two sets reliably. As a result of this, since the variances of the scores for the two samples were not similar, the alternative t-test was used. The results are shown in Table 15-4. Twelve significant differences were found. From a psychodynamic perspective, the interesting differences are a reduction in anxiety in the later poems, fewer references to people, and a greater emphasis on the past. But the differences are not as extensive or as relevant for understanding Kees's state of mind as those identified in the section above on Sylvia Plath's poems.

\subsection{Katie's Poems ${ }^{52}$}

In Chapter 3, the diary left by a young woman, Katie, who killed herself was analyzed. Katie also wrote poems and dated some of them by the year in which they were written. These dated poems cover a four year period, and Katie died in the middle of the following year. The 83 dated poems were labeled by the year in which they were written and analyzed using the LIWC program. The correlations over the four years

52 This section was co-authored with Stephanie McSwain. 
(labeled 1, 2, 3 and 4) are shown in Table 15-5. Eleven significant changes were found and six trends.

Most of these poems were written by Katie prior to the period covered by her diary. Unlike the results for the diary, these were no changes in emotions over time for these poems. References to death and to religion did not change. There was less emphasis on the present and future over time, but no increase in references to the past. Katie seemed less concerned with cognitive processes and insight over time in these poems (words such as cause, know and ought and think, know and consider).

Tab. 15.5.: Correlations over the four years for 83 poems by Katie, labelled by the year each was written.

\begin{tabular}{ll}
\hline & Correlation \\
\hline Words per sentence & $0.23^{\star}$ \\
First person plural & $-0.27^{\star}$ \\
Total third person & $0.30^{\star \star}$ \\
Cognitive processes & $-0.25^{\star}$ \\
Other references to people & $0.24^{\star}$ \\
Present tense verbs & $-0.32^{\star \star}$ \\
Future tense verbs & $-0.31^{\star \star}$ \\
Up & $0.26^{\star}$ \\
Achievement & $-0.24^{\star}$ \\
Leisure & $0.24^{\star}$ \\
Swearing & $0.31^{\star \star}$ \\
Words in the dictionary & $-0.21 \#$ \\
Insight & $-0.20 \#$ \\
Social processes & $0.21 \#$ \\
Home & $0.19 \#$ \\
Sports & $0.19 \#$ \\
Body & $0.22 \#$ \\
\hline
\end{tabular}

* two-tailed $p<.05, * \star$ two-tailed $p<.01, \#$ trend (two-tailed $p<0.10)$

\subsection{Discussion}

This study of the poems of these poets who died by suicide did not identify as many interesting trends over time as their deaths came closer as did the studies of diaries. As mentioned above, perhaps the crafting of poems and the application of rules of 
sound and meter impair the direct and indirect communication of psychodynamic factors in the words and sentences written by these poets. Alternatively other techniques of studying poems (other than the LIWC) may prove more fruitful. 